\title{
Profil Penyimpanan Obat Pada Puskesmas di Kota Padang Sumatera Barat
}

\author{
(Drugs Storage Profile at Public Health Centrein The City of Padang West Sumatra)
}

\author{
Hansen Nasif*, Yelly Oktavia Sari, Zikra Rahmadriza \\ Fakultas Farmasi Universitas Andalas, Limau Manis, Kecamatan Pauh, Kota Padang, Sumatera Barat
}

\begin{abstract}
Drug storage is an important factor in drug management at the Public Health Center, because with proper storage it will be easier and more effective to ensure the quality and quality of drugs. This study aims to obtain a systematic and accurate description of drug storage at the Padang City Public Health Center, West Sumatra Province. This research was conducted at 11 public health centers in 11 districts in the city of Padang. Collecting data through a checklist on aspects of drug storage at the Public Health Center which includes requirements for drug storage warehouses with 11 assessed aspects, drug storage arrangements with 7 assessed aspects and drug preparation procedures with 8 assessed aspects. There are still a number of problems encountered in the field, such as the storage space for drugs that is not up to standard, and the placement of drugs in the warehouse directly on the floor and not on pallets. However, in general, the results of this study indicate that drug storage, drug storage arrangements, and drug preparation procedures in 11 Public Health Center in all districts in the city of Padang are categorized as good with consecutive results of $86.36 \% ; 91.81 \%$ and $93.18 \%$.
\end{abstract}

Keywords: public health center; storage; drugs; Padang.

ABSTRAK: Penyimpanan obat menjadi faktor penting dalam pengelolaan obat di Puskesmas, karena dengan penyimpanan yang benar akan lebih mudah dan efektif untuk menjamin kualitas dan mutu obat. Penelitian ini bertujuan untuk mendapatkan gambaran secara sistematis dan akurat mengenai penyimpanan obat di Puskesmas kota Padang Provinsi Sumatera Barat. Penelitian ini dilakukan pada 11 puskesmas di 11 Kecamatan di Kota Padang. Pengambilan data melalui daftar tilik tentang aspek penyimpanan obat di puskesmas yang meliputi persyaratan gudang penyimpanan obat dengan 11 aspek yang dinilai, pengaturan penyimpanan obat dengan 7 aspek yang dinilai dan tata cara penyusunan obat dengan 8 aspek yang dinilai. Masih terdapat beberapa masalah yang ditemui di lapangan seperti, ruang gudang penyimpanan obat yang belum sesuai standar, dan penempatan obat di gudang langsung di lantai saja dan tidak diatas pallet. Namun secara umum, hasil penelitian ini menunjukkan bahwa penyimpanan obat, pengaturan penyimpanan obat, dan tata cara penyusunan obat di 11 puskesmas pada semua kecamatan di kota Padang dikategorikan baik dengan hasil secara berurutan 86,36\%; 91,81\% dan 93,18\%.

Kata kunci: puskesmas; penyimpanan; obat ; Padang.

\section{Pendahuluan}

Pengelolaan obat merupakan salah satu kegiatan yang dimulai dari perencanaan, permintaan, penerimaan, penyimpanan, pendistribusian, pengendalian, pencatatan dan pelaporan, serta pemantauan dan evaluasi. Tujuannya adalah untuk menjamin tercapainya ketepatan jumlah dan jenis perbekalan farmasi untuk mencapai tujuan yang ditetapkan pada berbagiai tingkat unit kerja. penyimpanan dan distribusi obat yang tepat sangat penting untuk menjamin efek obat dalam tubuh dan sudah seharusnya semua obat harus disimpan di tempat penyimpanan yang tepat $[1,2]$.

Penyimpanan obat juga merupakan kegiatan pengamanan sediaan dengan menempatkan obat yang diterima di tempat yang dinilai aman (agar tidak hilang), terhindar dari kerusakan fisik maupun kimia serta mutunya tetap terjamin, sesuai dengan standar yang telah ditetapkan. Kegiatan penyimpanan yang dimaksud meliputi beberapa faktor diantaranya ,pengaturan tata ruang dan penyusunan stok obat, pengamanan mutu obat serta pencatatan stok obat.Penyimpanan obat berfungsi memelihara mutu sediaan obat, menjamin ketersediaan obat serta memudahkan pencarian dan pengawasan sediaan obat [2-5].

Penyimpanan obat menjadi faktor penting dalam pengelolaan obat di Puskesmas, karena dengan penyimpanan yang benar akan lebih mudah dan efektif untuk mengumpulkan obat, dan pelayanan kesehatan tingkat pertama akan lebih baik. Penyimpanan obat juga bertujuan

*Corresponding Author: Hansen Nasif Fakultas Farmasi Universitas Andalas Limau Manis, Kecamatan. Pauh, Kota Padang, Sumatera Barat 25175 | Email: hansennasif7@gmail.com

\section{Article history}

Received: 30 Sep 2021 Accepted: 29 Nov 2021 Published: 07 Des 2021

Access this article

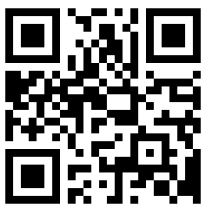


untuk memastikan ketersediaan obat yang berkualitas di unit pelayanan kesehatan [6].

Puskesmas adalah salah satu sarana pelayanan kesehatan masyarakat yang amat penting di Indonesia yang merupakan unit pelaksana fungsional yang berfungsi sebagai pusat pembangunan kesehatan, pusat pembinaan peran serta masyarakat dalam bidang kesehatan. Puskesmas memberikan pelayanan kesehatan tingkat pertama yang menyelenggarakan kegiatannya secara menyeluruh, terpadu dan berkesinambungan pada suatu masyarakat yang bertempat tinggal dalam suatu wilayah tertent. Pengelolaan obat di puskesmas perlu diperhatikan dengan baik karena pengelolaan obat yang efisien sangat menentukan keberhasilan terapi pasien [6].

Pusat Kesehatan Masyarakat (Puskesmas) adalah fasilitas pelayanan kesehatan yang menyelenggarakan upaya kesehatan masyarakat dan upaya kesehatan perseorangan tingkat pertama [7,8]. Masih kurangnya sarana dan prasarana di puskesmas merupakan salah satu alasan dilakukannnya penelitian ini, bahkan menurut [Fannya,2018] di Provinsi Sumatera barat masih terdapat 20,93\% Puskesmas yang masih kekurangan tenaga dokter serta 39,53\% kekurangan tenaga perawat [9], bahkan menurut Saputro (2017), yang melakukan penelitian di puskesmas kecamatan kuranji kota padang masih terdapat kurang memadai nya sumber daya di puskesmas [10].

Pemerintah Kota Padang yang merupakan ibukota propinsi Sumatera Barat pada sisi lain justru memiliki Perda No.05 tahun 2009 tentang pelayanan kesehatan gratis di Kota Padang, bahkan dengan bantuan Badan Zakat daerah (Bazda) pasien yang berkunjung ke puskesmas justru dapat penggantian uang transport sehingga meningkatkan kunjungan pasien ke puskesmas dan tentunya mengakibatkan makin tingginya penggunaan obat di puskesmas. Kedua hal diatas justru dapat meningkatkan keinginan untuk mempelajari tentang profil penyimpanan obat di Puskesmas [11].

Makin banyaknya obat yang disimpan di puskesmas juga akan membawa permasalahan tersendiri misalnya akan dibutuhkan Sarana penyimpanan yang lebih luas atau penanganan lain yang lebih komplek, seperti yang didapatkan pada penelitian Akbar dkk tahun 2016, yang melakukan analisis penyimpanan obat di Puskesmas se kota Banjarbaru yang dengan penekanan pada stok obat yang kadaluarsa mendapatkan hasil pada tahun 2014 dan 2015 di dapatkan obat kadaluarsa dengan rata-rata 0,51\% dengan nilai kerugian lebih dari Rp. 30 juta. [12], sedangkan pada penelitian murniati ( 2019) didapatkan hasil bahwa penyimpanan obat pada puskesmas Antang kota Makasar hanya masuk kategori cukup dengan skor 62.5\% [13], padahal pemerintah sudah mengeluarkan aturan yang jelas pada penyimpanan obat yang bertujuan memelihara mutu obat dengan memperhatikan aspek umum dan aspek khusus sesuai aturan yang telah ditetapkan Kemenkes[14,15] dan pengelolaan sediaan farmasi penanggung jawabnya adalah Apoteker, kecuali untuk Puskesmas yang belum memiliki Apoteker bisa dilakukan oleh Tenaga Teknis Kefarmasian tapi tetap di bawah pembinaan dan pengawasan apoteker yang ditunjuk oleh Kepala Dinas Kesehatan Kabupaten/ Kota [16].

\section{Metode Penelitian}

Penelitian ini merupakan suatu penelitian observasi prospektif. Sampel pada penelitian ini diperoleh dari Puskesmas pada semua kecamatan di Kota Padang Provinsi Sumatera Barat. Jika pada satu kecamatan terdapat lebih dari satu puskesmas akan dipilih puskesmas yang paling banyak dikunjungi pasien. Pengambilan data dilakukan pada 11 puskesmas di 11 kecamatan di Kota Padang.

Pengambilan data melalui lembar checklist daftar aspek penilaian penyimpanan obat di puskesmas dari Kemenkes RI [17], yang meliputi persyaratan gudang penyimpanan obat dengan 11 aspek yang dinilai, pengaturan penyimpanan obat dengan 7 aspek yang dinilai dan tata cara penyusunan obat dengan 8 aspek yang dinilai.

Data yang diperoleh kemudian dianalisa secara deskriptif dengan kategori, setiap jawaban "ya" akan diberi nilai 1, jika jawaban " tidak" nilainya nol. Lalu akan dibuat presentase jawaban "ya' dan 'tidak" melalui perbandingan jumlah skor yang diperoleh dibandingkan dengan maksimum skor yang bisa didapatkan dikali dengan 100\%, seperti tertera pada bagian bawah tabel 1, 2 dan 3 untuk masing-masing puskesmas. Hasil penilaian ditetapkan sebagai berikut, Baik jika $=>75 \%$, Cukup jika $60-75 \%$, dan Kurang jika $=<60 \%$ [18].

\section{Hasil dan Diskusi}

\section{Persyaratan Gudang Penyimpanan Obat}

Pada Penelitian yang ini masih terdapat beberapa masalah yang harus di perhatikan yaitu tidak semua puskesmas melengkapi pintu gudang dengan kunci ganda hal ini akan memudahkan obat untuk dicuri ataupun di rusak oleh pihak yang tidak bertanggung jawab. Masih terdapat beberapa puskesmas yang tidak memiliki ventilasi yang cukup di bagian penyimpanan gudang obat padahal kondisi ini bisa membuat sirkulasi udara tidak lancar [14].

Pada beberapa puskesmas masalah yang harus diperhatikan yaitu luas gudang penyimpanan obat tidak 


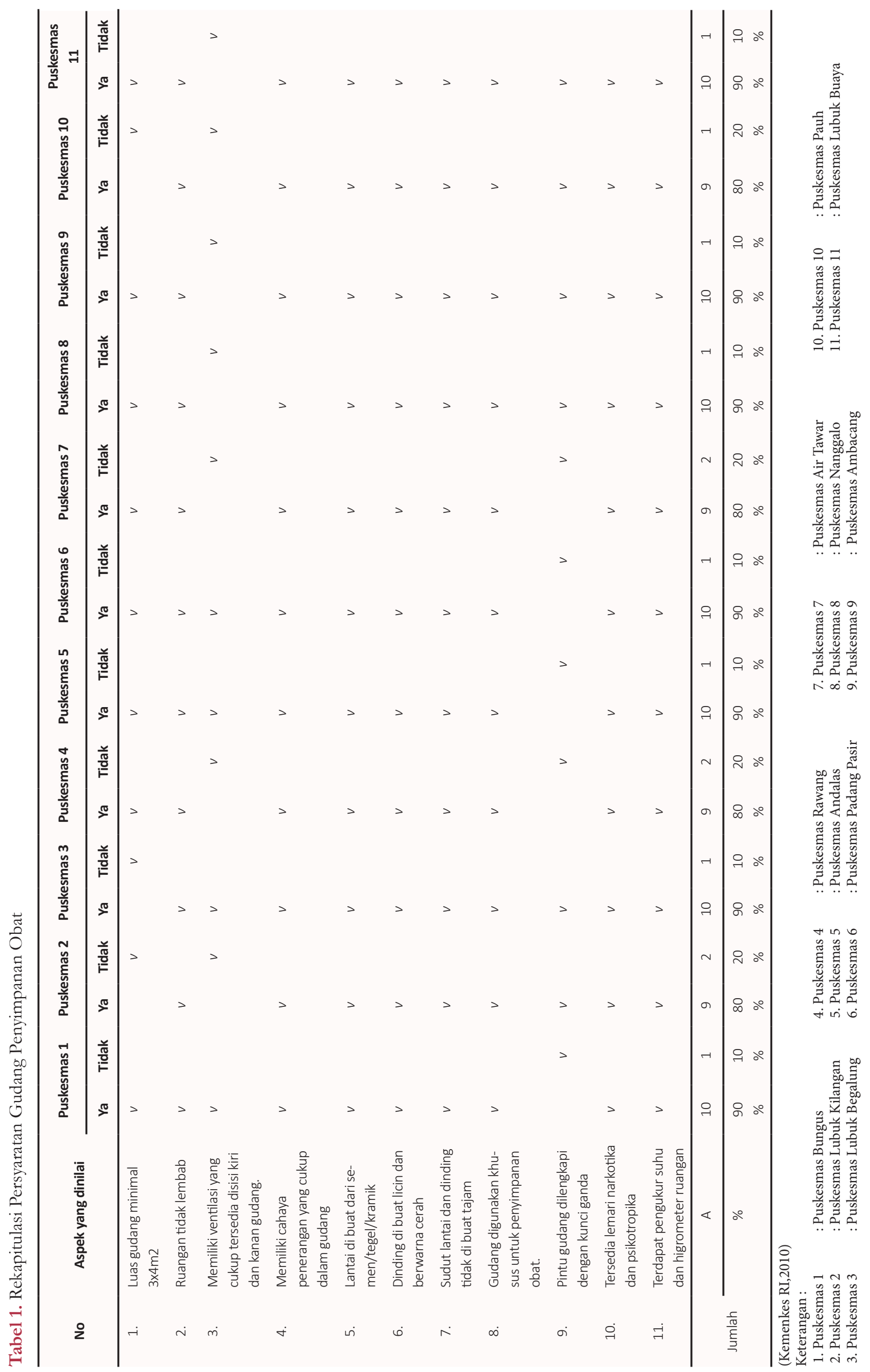




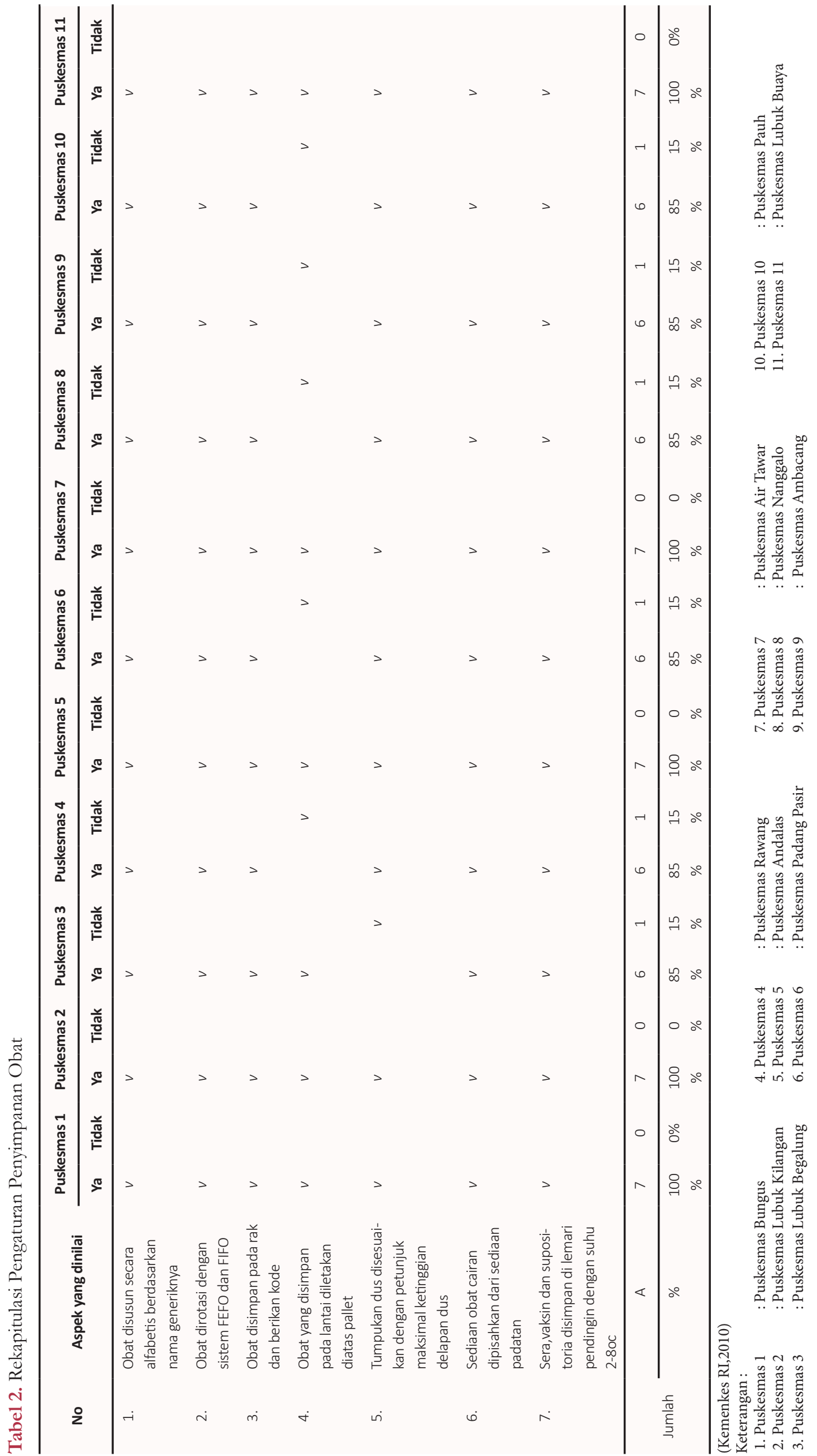




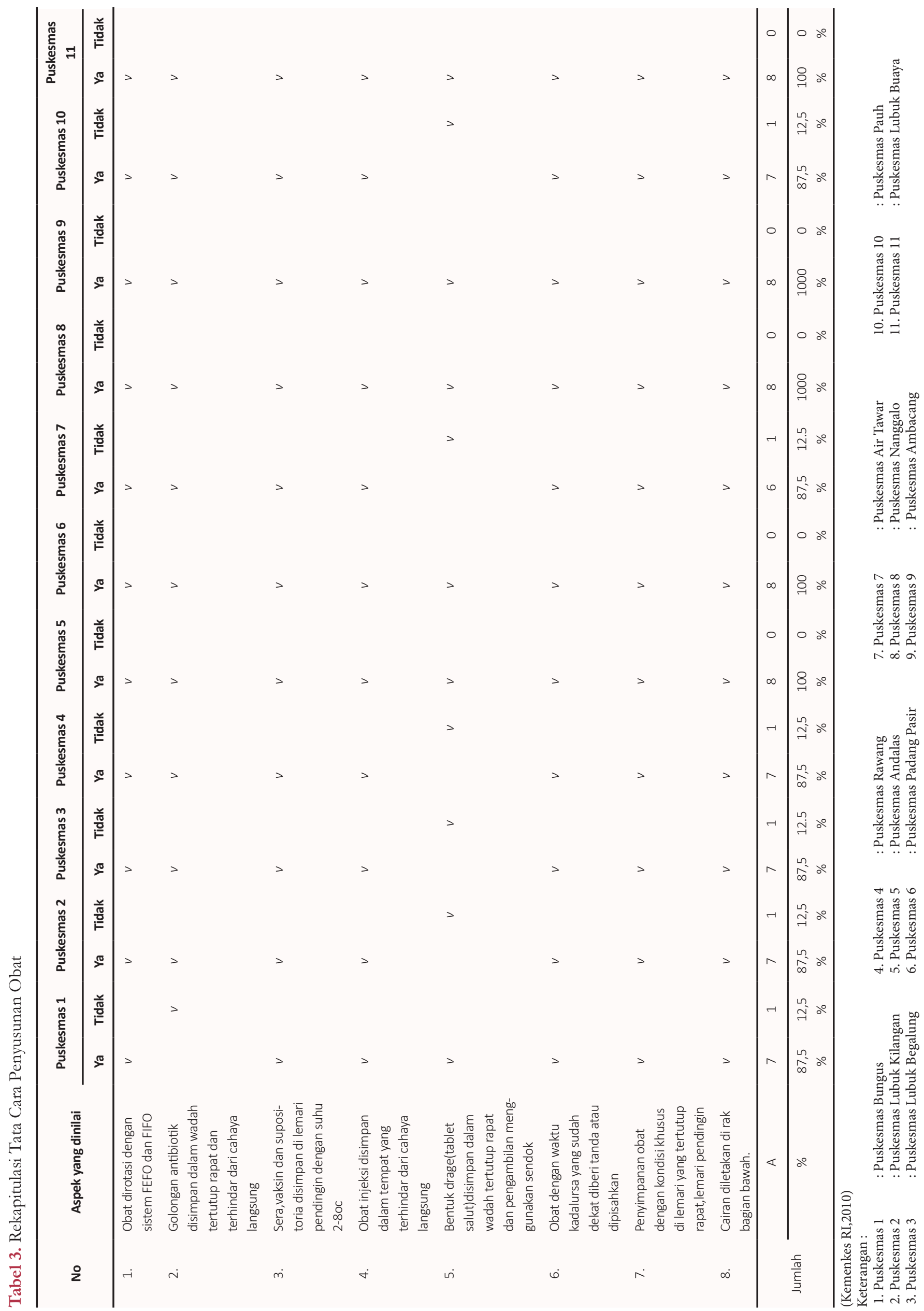


memenuhi standar pelayanan kefarmasian di puskesmas yaitu $3 \times 4 \mathrm{~m}^{2}$ dimana masih ada beberapa puskesmas yang ruangan gudang penyimpanan obatnya tidak sesuai standar sehingga menyebabkan obat bertumpuk dan susah untuk menyimpan obat dalam kapasitas yang banyak.

Untuk parameter yang lainnya secara umum sudah memenuhi syarat standar pelayanan kefarmasian di puskesmas seperti tersedianya lemari narkotika dan psikotropika memiliki dua pintu dan menempel di tembok yang terkunci untuk penyimpanan obat narkotika dan psikotropika agar terhindar dari salah pengambilan obat oleh petugas gudang dan mudah membedakan dengan obat lain. Penelitian yang dilakukan oleh Sindarto (2013) dan Anggraini (2013), yang melakukan penelitian di tempat berbeda juga mendapatkan hal yang sama saat melakukan penelitian tentang penyimpanan obat di dua kecamatan di Kota Surabaya dan di Kota Palangkaraya [19,20].

Hasil tabulasi pada tabel 1 memperlihatkan Persyaratan gudang penyimpanan obat yang dilakukan pada Puskesmas Dalam Wilayah Kerja Dinas Kesehatan Kota Padang yang meliputi sarana dan prasarana dirataratakan dengan persentase $86,36 \%$, sehingga masuk kategori baik.

\section{Pengaturan Penyimpanan Obat}

Rekapitulasi hasil pengaturan penyimpanan obat seperti tertera pada tabel 2, menunjukkan bahwa pada sebagian besar puskesmas sudah memenuhi persyaratan sesuai standar pelayanan kefamasian di puskesmas, walaupun masih ada beberapa masalah di sebagian puskesmas lainnya misal adanya obat yang disimpan pada lantai tidak diletakkan diatas pallet dan ada juga puskesmas tidak memiliki pallet sehingga obat langsung diletakkan di lantai.Penelitian sejenis yang dilakukan Wahyuni (2019) juga mendapatkan hal seperti ini, padahal pallet juga bisa membantu untuk meningkatkan sirkulasi udara di dalam gudang penyimpanan obat [21].

Masalah lain yang ditemukan yaitu adanya puskesmas yang tidak memperhatikan penyusunan obat pada tumpukan dus (box kotak obat) yang seharusnya disesuaikan dengan petunjuk pada karton box tersebut, Jika tidak tertulis pada karton maka maksimal ketinggian tumpukkan harusnya delapan dus, tumpukkan dus sangat perlu diperhatikan karena obat yang ada di dalam dus bagian tengah ke bawah dapat pecah dan rusak dan selain itu akan menyulitkan dalam pengambilan obat.

Pada hasil rekapitulasi Tabel 2, diketahui bahwa pengaturan penyimpanan obat yang dilakukan pada Puskesmas di Kota Padang yang meliputi keadaan pengaturan penyimpanan obat di dapatkan hasil 91,81\% yang dikategorikan baik.

\section{Tata Cara Penyusunan Obat}

Obat merupakan salah satu faktor terpenting dalam pelayanan kesehatan, oleh karena itu penting sekali untuk memperhatikan tata cara penyusunan obat baik di rumah sakit, puskesmas, ataupun di gudang farmasi. Penyusunan obat bisa dalam 2 kategori yaitu penyusunan obat berdasarkan abjad dan penyusunan obat berdasarkan kelas terapi untuk memudahkan pencarian obat, memudahkan pengawasan dan pengendalian stok khususnya bagi obat dengan golongan psikotropika dan narkotika, obat yang mempunyai waktu kadaluarsa, serta untuk menjaga stabilitas obat. Obat yang kadaluarsa sudah diberi tanda khusus atau dipisahkan. Dilihat dari berbagai macam parameter penilaian, semua puskesmas sudah menerapkan sistem FIFO dan FEFO, hal ini juga ditemukan peneliti lain yaitu Wijana (2020) yang melakukan penelitian di Puskesmas Rejo Katon, Kecamatan Raman Utara, Kabupaten lampung Timur [22]. Obat antibiotik disimpan di tempat yg terhindar dari cahaya matahari dan di tempat yang kering, dan tablet salut disimpan dalam wadah tertutup rapat dan pengambilannya menggunakkan sendok. Parameter lainnya yaitu serum,vaksin harus dalam wadah yang tertutup rapat dan diletakkan di lemari pendingin dengan suhu 2-8 $8^{\circ}$.semua hal diatas secara umum sudah dilaksanakan dengan baik.

Hasil rekapitulasi pada Tabel 3 memperlihatkan bahwa sistem tata cara penyusunan obat pada sebagian besar puskesmas sudah memenuhi persyaratan standar pelayanan kefarmasian di puskesmas dengan persentase kesesuaian yang diperoleh sebesar 93,18\%. Hasil ini sangat baik dibanding penelitian sejenis yang telah dilakukan oleh Hurria (2019) yang hanya mendapatkan hasil 61\% saat melakukan penelitian sejenis pada pengaturan penyimpanan obat di puskesmas Tompobolu Kabupaten Moros [23].

\section{Kesimpulan}

Kesimpulan yang bisa dihasilkan dari penelitian ini adalah, persyaratan gudang penyimpanan obat di 11 puskesmas di tiap kecamatan di kota Padang didapatkan dalam kategori baik dengan hasil persentase 86,36\%. Untuk pengaturan penyimpanan obat didapatkan kategori baik dengan hasil 91,81\% dan untuk tata cara penyusunan obat di Puskesmas di tiap kecamatan di Kota Padang juga dikategorikan baik dengan persentase 93,18\%. 


\section{Ucapan Terimakasih}

Kami tim peneliti mengucapkan Terimakasih yang sebesar-besarnya kepada Fakultas Farmasi Unand Padang yang telah mendanai penelitian ini melalui Dana DIPA Fakultas Farmasi Universitas Andalas tahun 2021 dengan nomor kontrak 03/UN16.10.D/PJ.01./2021.

\section{Referensi}

[1]. Padang SA dan Tonglo E. Gambaran Tata Kelola Obat Kegawatdaruratan di Seluruh Puskesmas Rawat Inap Kabupaten Toraja Utara Periode Agustus 2018.Media Farm. 2019; XV(1): 1-7 https://doi.org/10.32382/mf.v15i1.850

[2]. Ali SA, Suhail N. Importance of storing medicine on required temprature in pharmacies and role of community pharmacies in rural areas:Literature review. I-manager's Journal in Nursing. 2016; 6(1): 17-27

[3]. Menkes RI. Peraturan Menteri Kesehatan Republik Indonesia No. 74 Tahun 2016 Tentang Standar Pelayanan Kefarmasian di Puskesmas. Jakarta; 2016.

[4]. Agfary M, Ishfahani F,Mahieu MTR. Evaluasi Penyimpanan obat dan Alat Kesehatan di Apotek Restu Farma. Jurnal Farma Medika 2018 ; 3 (1):10-20

[5]. Wardhana ZP. Profil Penyimpanan Obat Di Puskemas Pada Dua Kecamatan yang Berada di Kota Kediri. Calyptra J ilmiah mahasiswa Univ Surabaya. 2013;2(2):1-9.

[6]. Khoirurrizza M, Mandagi CKF, Kolibu FK, Kesehatan F, Universitas M, Ratulangi S, et al. Analisis Proses Penyimpanan Obat Di Puskesmas Teling Atas Kecamatan Wanea Kota Manado. Kesmas. 2017;6(4):1-1

[7]. Kementrian Kesehatan RI. Peraturan Menteri Kesehatan Nomor 75 tahun 2014.Jakarta. Kementrian Kesehatan RI

[8]. Alfian A dan Basra MU. Analisis Pelaksanaan E-Puskesmas di Puskesmas Ikur Koto Padang. Jurnal endurance: kajian IImiah Problema Kesehatan.2020;2 (2):1-8

[9]. Fannya P, Sulastri D, Rasyid R. Analisis mutu pelayanan puskesmas kota Padang menggunakan teknik importance Performance Analysis. Jurnal Kesehatan Medika Saintika. 2018; 9 (2): 1-11
[10]. Saputro AB, Adnan MF, Alhadi Z. Pelaksanaan layanan e-puskesmas di puskesmas ambacang kecamatan kuranji Kota Padang. Journal of public sector innovations. 2017;2 (1):1-6.

[11]. Syah I, Darwin E, Bachtiar H, Pujani V. Pengembangan Model Kebijakan pelayanan gratis di puskesmas. Jurnal Kesehatan Masyarakat Nasional. 2014 ; 8 (7): 1-5.

[12]. Akbar NH, Kartinah N, Wijaya C. Analisis managemen penyimpanan obat di puskesmas se-kota Banjarbaru. Jurnal managemen dan pelayanan farmasi. 2016; 6 (4):1-6

[13]. Murniati. Gambaran cara pengelolaan obat pada tahap penyimpanan di puskesmas antang kota makasar.2019; V (2):133136. https: //doi.org/10.36060/

[14]. Departemen Kesehatan RI, Pedoman Pengelolaan Obat Publik dan Perbekalan Kesehatan. Jakarta; 2002.

[15]. Kemenkes RI. Petunjuk Teknis Standar Pelayanan Kefarmasian Di Puskesmas. Jakarta. Kementrian Kesehatan RI. 2019

[16]. Depkes RI. Peraturan Kementerian KesehatanNomor 26 tahun 2020 tentang Standar Pelayanan Kefarmasian di Puskesmas. Jakarta: 2020

[17]. Kemenkes RI. Materi Pelatihan Manajemen Kefarmasian di Puskesmas. Jakarta; 2010

[18]. Arikunto S. Prosedur Penelitian Suatu Pendekatan Praktis. Jakarta: Rineka Cipta; 2006

[19]. Sindarto IP.Studi penyimpanan obat di puskesmas pada dua kecamatan di Kota Surabaya. Calyptra J ilmiah mahasiswa Univ Surabaya. 2013;2(2):1-8.

[20]. Anggraini C. Kajian kesesuaian penyimpanan sediaan obat pada dua puskesmas yang ada di Kota Palangkaraya.Calyptra J ilmiah mahasiswa Univ Surabaya. 2013;2(2):1-11.

[21]. Wahyuni A. Ariski S. Yuliana I. Evaluasi penyimpanan sediaan farmasi di gudang puskesmas se kota banjarmasin. Jurnal Insan Farmasi Indonesia. 2019. 2;(2) 166-174, https://doi.org/10.36387/jifi. v2i2.412

[22]. Wijana IK, Sari FE, Aryastuti N. Analisis Penyimpanan obat di Puskesmas Rejo Katon Kecamatan Raman Utara Kabupaten lampung Timur. Jurnal Dunis Kesmas 2020 9;(2):206-214, https://doi. org/10.33024/jdk.v9i2.2896

[23]. Hurria dan Sakri M. Profil pengelolaan penyimpanan obat di Puskesmas Tompobulu Kabupaten Maros.Jurnal Farmasi FIK UINAM. 2019;7 (1):1-8. 